\title{
Sosialisasi Keselamatan Transportasi Supir AKDP Kota Makassar
}

\author{
Indriaty Wulansari ${ }^{{ }^{*}}$ \\ 1* Program Studi Teknik Sipil, Fakultas Teknik, Universitas Atma Jaya Makassar, Jl. Tanjung Alang No 23 \\ Makassar, Provinsi Sulawesi Selatan, Indonesia \\ Corresponding Email: indriaty.wulansari@gmail.com ${ }^{1}$
}

Histori Artikel:

Diterima 16 December 2021; Diterima dalam bentuk revisi 13 Januari 2022; Diterima 2 Februari 2022; Diterbitkan 6 Februari 2022. Semua hak dilindungi oleh Lembaga Peneltiian dan Pengabdian Masyarakat (LPPM) AMIK Indonesia.

\begin{abstract}
Abstrak
Alat transportasi umum merupakan suatu kebutuhan alternatif bagi masyrakat yang menunjang kehidupan dalam berbagai kegiatan. Penegakan hukum berperanan sangat penting. Undang-undang beserta perangkat peraturan pelaksanaannya perlu disebarluaskan agar masyarakat dapat memahaminya, termasuk penjelasan sanksi pelanggarannya. tujuan dari kegiatan sosialisasi antara lain untuk memberikan pemahaman kepada supir AKDP tentang PP RI N0 55 tahun 2012 tentang kendaraan dan UU No 22 tahun 2009 tentang lalulintas angkutan jalan. Sebelum sosialisasi dilakukan, terlihat bahwa supir AKDP masih belum memahami tentang RI N0 55 tahun 2012 tentang kendaraan dan UU No 22 tahun 2009 tentang lalulintas angkutan jalan, hal ini terlihat pada persentase hasil pretest. Setelah sosialisasi dilakukan, tingkat pemahaman supir tentang tujuan sosialisasi sudah meningkat. Hal ini terlihat pada persentase hasil post-test yang dilakukan langsung dilapangan.
\end{abstract}

Kata Kunci: Sosialisasi; Keselamatan Transportasi; Supir AKDP.

\section{Pendahuluan}

Transportasi merupakan Suatu Sistem. Sistem adalah gabungan beberapa komponen yang saling berhubungan atau objek yang saling berkaitan dan saling mempengaruhi. Dikarenakan dalam transportasi terdapat banyak komponen yang saling terkait dan saling mempengaruhi, maka transportasi dapat dikatakan sebagai suatu sistem [1]. Menurut Permenhub (2015) tentang standar keselamatan lalu lintas dan angkutan jalan menyatakan bahwa keselamatan merupakan suatu keadaan terhindarnya setiap orang dari resiko kecelakaan selama berlalu lintas yang disebabkan oleh manusia, kendaraan, jalan, dan/atau lingkungan. Standar keselamatan bidang lalu lintas dan angkutan jalan sebagaimana dimaksud pada ayat (2), merupakan acuan bagi penyelenggara sarana dan prasarana bidang lalu lintas dan angkutan jalan yang meliputi: a) kendaraan bermotor umum; b) prasarana lalu lintas dan angkutan jalan), sumber daya manusia di bidang lalu lintas dan angkutan jalan; d) operasional; dan e) Lingkungan [2].

Di dalam dunia yang menyatu, perangkutan sebagai tatanan mobilitas, sosial, budaya, ekonomi, dan hankam dituntut untuk lebih cepat, lebih andal, lebih efisien, dengan daya saing yang tinggi. Oleh karena itu, masalah perangkutan dan lalu lintas dicoba dipilah untuk memudahkan para penentu kebijakan melihat lebih tajam berbagai permasalahan yang ada, dengan begitu mereka dapat menentukan kebijakan mengenai perangkutan dan lalu lintas yang paling tepat untuk diterapkan, baik di lingkup daerah maupun nasional [3]. Alat transportasi umum merupakan suatu kebutuhan alternatif bagi masyarakat yang menujang kehidupan dalam berbagai kegiatan. Namun alat transportasi umum yang kita jumpai saat ini sudah kurang layak untuk kita acungi jempol, dengan berbagai permasalahan dan pelanggaran-pelanggaran yang kita saksikan saat ini, menyebabkan berbagai permasalahan sosial. Salah satu permasalahan yang dihadapi di kota-kota besar di 
Indonesia adalah kesemrawutan dan kemacetan lalu lintas. Pemerintah kota dituntut menyediakan transportasi angkutan umum yang aman dan nyaman bagi masyarakatnya. Pelanggaran alat transportasi umum yang kita temui sehari-harinya mungkin sudah menjadi kebiasaan yang di maklumi, namun juga pelanggaran tersebut berdampak pada masalah sosial di masyarakat, pelanggaran-pelangaran umun yang kita dapati di lapangan biasanya ialah angkutan umum yang ugalugalan, menurunkan dan mengambil penumpang di sembarang tempat, serta menerobos lampu lalu lintas.

Ketidakdisiplinan selalu merupakan alasan utama terjadinya permasalahan transportasi perkotaan. Bagaimana pun baiknya sistem perlalulintasan, jika tidak dibarengi dengan disiplin berlalulintas yang baik, akan tetap berakhir dengan masalah. Selain itu, disiplin tidaknya pengguna jalan tidak saja tergantung pada dirinya sendiri, tetapi juga pada ketegasan sistem perlalulintasan yang berlaku, termasuk undang-undang dan peraturan, penegakan hukum, sosialisasi hukum, sarana, dan prasarana. Penegakan hukum berperanan sangat penting. Undang-undang beserta perangkat peraturan pelaksanaannya perlu disebarluaskan agar masyarakat dapat memahaminya, termasuk penjelasan sanksi pelanggarannya [4]. Aspek keselamatan dalam berlalu lintas dipengaruhi oleh beberapa hal yaitu kualitas pengemudi, kelayakan kendaraan, dan sarana prasarana yang memenuhi standar keselamatan. Jika salah satu komponen ini tidak baik atau tidak memenuhi syarat, maka kemungkinan terjadi pelanggaran lalu lintas yang dapat menimbulkan kecelakaan lalu lintas menjadi besar. Masalah lalu lintas yang semakin kompleks seiring dengan pertambahan penduduk dan perkembangan dinamika masyarakat, menuntut Polri untuk bekerja lebih keras dengan paradigma baru untuk dapat menjadi Polisi yang ideal dimasyarakat. Agar dapat terlaksana transportasi dengan aman dan nyaman, maka sebagai masyarakat umum, hendaknya kita membantu tugas Polisi dalam menciptakan transportasi yang aman dan berkelanjutan.

Dalam rangka menanggulangi pelanggaran lalu lintas maka dirumuskan suatu peraturan perundang-undangan. Menurut UndangUndang Nomor 22 Tahun 2009 tentang Lalu Lintas dan Angkutan jalan yang di dalamnya berisi pengaturan dan penerapan sanksi bagi suatu pelanggar. Hal ini dimaksudkan uutuk menimbulkan efek jera bagi pelaku agar tidak terlalu membebani masyarakat. Disahkannya Undang-Undang Nomor 22 Tahun 2009 merupakan awal perubahan sistem dalam pengaturan lalu lintas dan penerapan sanksi atas pelanggaran lalu lintas. Menurut PP No 55 tahun 2012, Setiap Kendaraan Bermotor yang dioperasikan di jalan harus memenuhi persyaratan teknis. (2) Persyaratan teknis sebagaimana dimaksud pada ayat (1) terdiri atas: a. susunan; b. perlengkapan; c. ukuran; d. karoseri; e. rancangan teknis Kendaraan sesuai dengan peruntukannya; f. pemuatan; g. penggunaan; h. penggandengan Kendaraan Bermotor; dan/atau i. penempelan Kendaraan Bermotor.

Menurut Akbar, S.A (2015), bahwa dalam Pasal 1 ayat (1) Undang-Undang Lalu Lintas dan Angkutan Jalan [5]. "Lalu lintas dan Angkutan Jalan adalah satu kesatuan sistem yang terdiri atas Lalu Lintas, Angkutan Jalan, jaringan Lalu Lintas dan Angkutan Jalan, prasana Lalu Lintas dan Angkutan Jalan, kendaraan, pengemudi, pengguna jalan, serta pengelolanya".Pasal 1 ayat (2) Undang-Undang Lalu Lintas dan Angkutan Jalan."Lalu Lintas adalah gerak kendaraan dan orang di ruang Lalu Lintas Jalan”.Pasal 1 ayat (3) Undang-Undang Lalu Lintas dan Angkutan Jalan."Angkutan adalah perpindahan orang dan/atau barang dari satu tempat ke tempat lain dengan menggunakan kendaraan di ruang lalu lintas jalan".Melihat rumusan Pasal 1 ayat (1), (2) dan (3) tersebut di atas dapat disimpulkan bahwa lalu lintas angkutan jalan adalah gerak pindah orang atau barang dari satu tempat ke tempat lain dengan menggunakan kendaraan dan sarana jalan yang diperuntukkan bagi umum. Penyidik Kepolisian Negara Republik Indonesia dan Penyidik Pegawai Negeri Sipil mempunyai kewenangan dalam pelaksanaan sanksi pelanggaran lalu lintas. Upaya penerapan Undang-Undang Lalu Lintas Nomor 22 Tahun 2009 pada angkutan transportasi umum dilakukan melalui peningkatan, pengawasan dibidang lalu lintas dan angkutan jalan yang lebih intensif. Upaya penegakan hukum dilaksanakan lebih efektif melalui perumusan ketentuan hukum yang lebih jelas serta penerapan sanksi yang lebih tegas untuk menekan angka pelanggaran lalu lintas dan kecelakaan. Berdasarkan latar belakang diatas, maka marilah kita senantiasa mengutamakan keselamatan transportasi dengan mematuhi segala aturan yang telah dibuat oleh instansi terkait agar pelaksanaan transportasi senantiasa lancar. 


\subsection{Tujuan Kegiatan}

Tujuan kegiatan pengabdian yang dilakukan adalah untuk mengetahui sejauh mana pemahaman para supir AKDP tentang keselamatan transportasi khususnya tentang PP No 55 tahun 2012 dan UU No 22 tahun 2009 serta hukum yang berlaku dalam berlalulintas sebelum dan setelah sosialisasi.

\subsection{Manfaat Kegiatan}

Diharapkan supir AKDP dalam terminal Mallengkeri dapat mengetahui tentang keselamatan transportasi khususnya tentang PP No 55 tahun 2012 dan UU No 22 tahun 2009 serta hukum yang berlaku dalam berlalulintas sehingga dapat memberikan pelayanan yang aman dan nyaman bagi pengguna (masyarakat).

\section{Realisasi Kegiatan}

\subsection{Bentuk Kegiatan \& Jadwal, Serta Tempat Kegiatan \\ a. Metode Pelaksanaan Kegiatan}

Menurut Mead (2018) menyatakan bahwa sosialisasi adalah konsep umum yang diartikan sebuah proses di mana kita belajar interaksi dengan orang lain, tentang cara bertindak, berpikir, dan merasakan, di mana semua itu merupakan hal penting dalam menghasilkan partisipasi sosial yang efektif [6]. Proses tersebut harus bersifat mendidik, membimbing dan menerapkan, sehingga masyarakat dapat "menolong dirinya sendiri" (self help) mengubah memperbaiki tingkat pemikiran, tingkat kerja dan tingkat kesejahteraan hidupnya. Sosialisasi menurut kamus besar Bahasa Indonesia berarti upaya memasyarkatkan sesuatu sehingga menjadi dikenal, dipahami, dihayati oleh masyarakat atau pemasyarakatan. Sosialisasi itu sendiri sangat penting adanya, karena bila tidak ada sosialisasi maka bisa dipastikan apapun tujuan yang kita maksudkan untuk diri kita sendiri ataupun untuk orang lain tidak akan tercapai.

\section{b. Waktu Efektif Pelaksanaan Kegiatan}

Waktu dalam pelaksanaan kegiatan ini berlangsung pada tanggal 18 Desember 2021 menjelang libur Natal dan tahun baru.

\section{c. Tempat Kegiatan}

Tempat pelaksanaan pengabdian kepada masyarakat ini adalah Terminal Mallengkeri di Kota Makassar, Provinsi Sulawesi Selatan seperti pada Gambar 1.

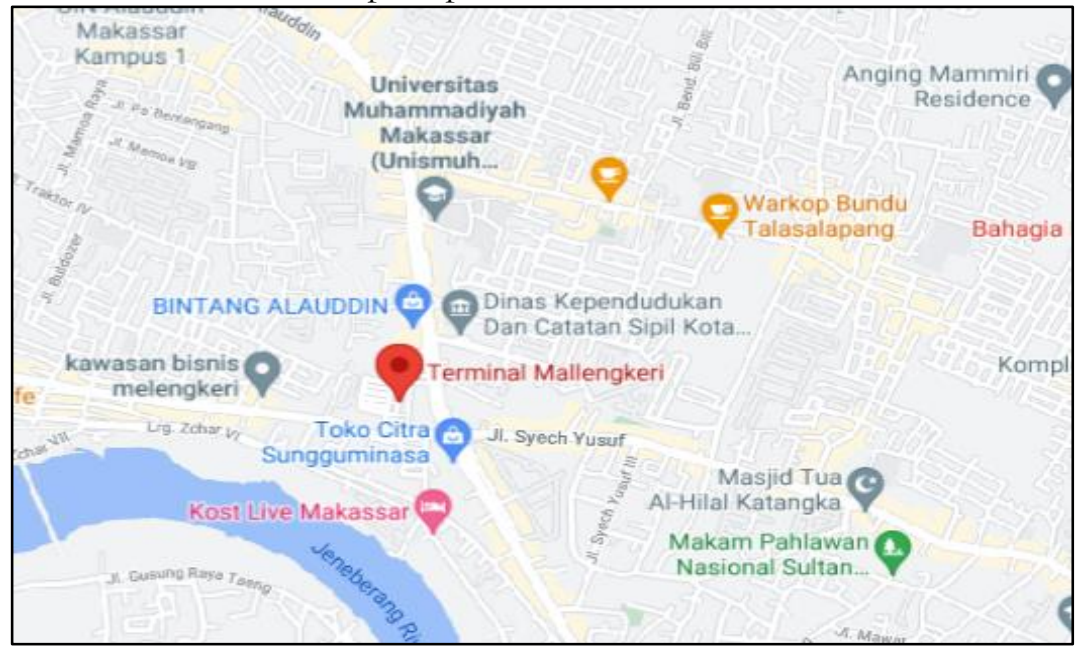

Gambar 1. Map Lokasi Kegiatan 


\subsection{Hasil Pelaksanaan Pengabdian}

\subsubsection{Pemaparan tentang tujuan Sosialisasi}

Pemaparan tentang tujuan dari kegiatan sosialisasi antara lain pentingnya pemahaman tentang keselamatan transportasi, kewajiban seorang supir sebelum dan setelah melaksanakan pengangkutan baik barang maupun penumpang dan tanggung jawab yang diemban selama perjalanan. Dokumentasi kegiatan ini dapat dilihat pada Gambar 2.
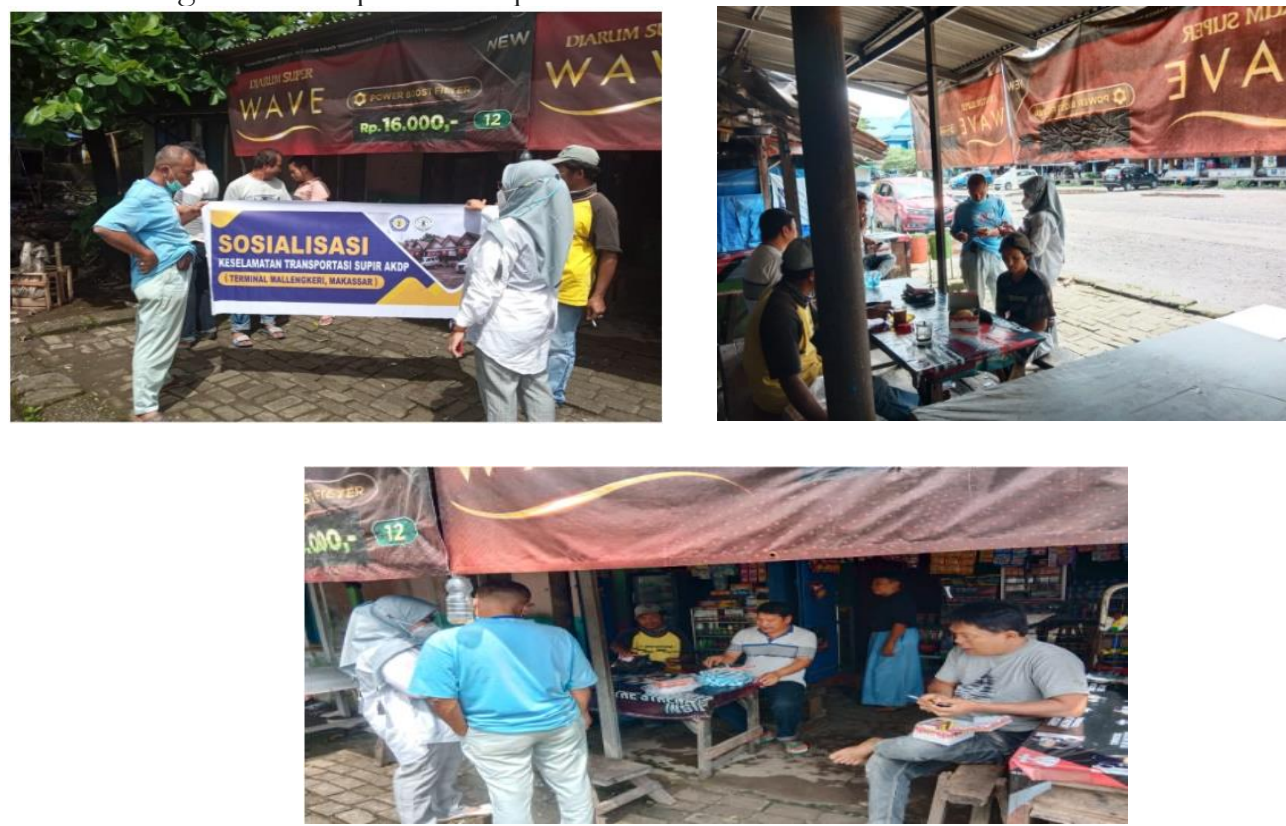

Gambar 2. Pemaparan tentang tujuan sosialisasi

\subsubsection{Pengenalan rambu lalu lintas}

Menurut Permenhub, 2014 tentang rambu lalu lintas menyatakan bahwa Rambu Lalu Lintas berdasarkan jenisnya terdiri atas: a) rambu peringatan; b) rambu larangan; c) rambu perintah; dan d) rambu petunjuk [7]. Sosialisasi tahap pertama adalah pengenalan rambu lalu lintas dengan cara memperlihatkan gambar beserta arti dari rambu tersebut. Terkait ini, dapat dilihat pada Gambar 3.
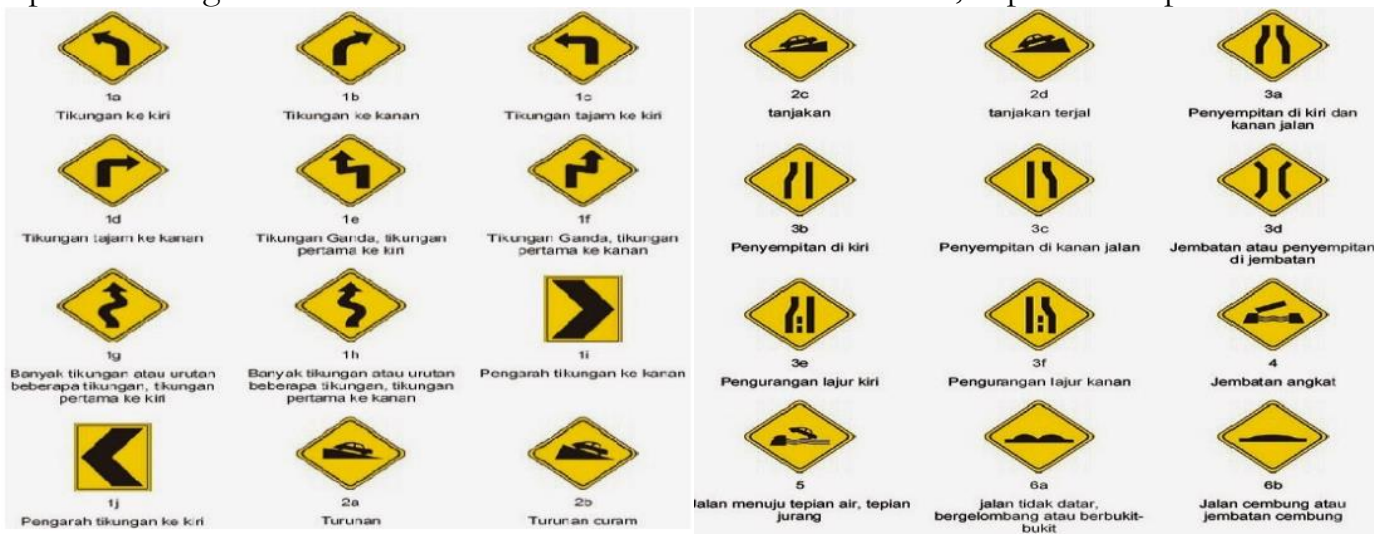

Gambar 3. Rambu lalu lintas dan artinya

Tindakan Pencegahan yang direkomendasikan dalam urutan prioritas antara lain ciptakan sebuah zona batas kecepatan $60 \mathrm{~km} /$ jam sepanjang jalan raya melalui kampung/desa, minimal sepanjang $1.000 \mathrm{~m}$, setelah membicarakannya dengan Polisi dan mencari dukungan mereka untuk pelaksanaan. Lalu, pasang rambu penunjuk arah yang baru $150 \mathrm{~m}$ di timur dan barat persimpangan di jalan raya. Selanjutnya pasang rambu peringatan baru (perempatan) $50 \mathrm{~m}$ di timur dan barat simpangan. Berikan marka garis tengah sepanjang jalan raya, berikan marka garis berhenti pada dua jalan kecil di persimpangan, bekali petugas lalu lintas dengan rompi yang memantulkan cahaya 
dengan jarak pandang tinggi, perintahkan mereka dalam pengendalian lalu lintas untuk persimpangan ini dan pasang sedikitnya satu lampu jalan disimpangan untuk menyoroti persimpangan saat gelap (Kementrian PU Bina Marga, 2012) [8].

Sosialisasi tahap kedua adalah menjelaskan tentang PP 55 tahun 2012 tentang Tata Cara Pemeriksaan Kendaraan Bermotor di Jalan dan Penindakan Pelanggaran Lalin dan Angkutan Jalan menegaskan bahwa Pemeriksaan Kendaraan Bermotor di Jalan pada dasarnya bertujuan untuk mendorong terciptanya kepatuhan dan budaya berlalu lintas, memastikan terpenuhinya persyaratan teknis dan persyaratan laik jalan Kendaraan Bermotor, memastikan terpenuhinya kelengkapan dokumen registrasi dan identifikasi pengemudi dan Kendaraan Bermotor serta dokumen perizinan dan kelengkapan Kendaraan Bermotor angkutan umum, serta mendukung pengungkapan perkara tindak pidana. Adapun PP No 55 tahun 2012 dibagi ke supir AKDP dalam bentuk Softcopy melalui link

https://drive.google.com/file/d/1Oqp5p5RUhBYuzXv3UEO2mHbGQW3h3hXr/view?usp=sha ring. Berikut tampilan depan dari PP 55 tahun 2012 yang telah disebar ke supir AKDP secara online pada Gambar 4

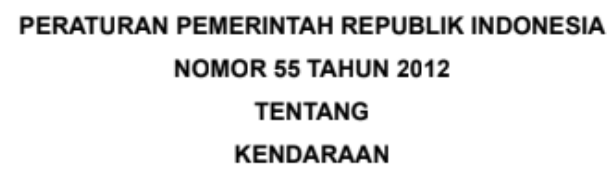

Gambar 4. PP RI No 55 tahun 2012

Sosialisasi tahap ketiga adalah menjelaskan tentang hukum pelanggaran yang berlaku dalam berlalulintas. Upaya penerapan Undang-Undang Lalu Lintas Nomor 22 Tahun 2009 (https://drive.google.com/file/d/1ufscdpb5mLc4zSwHHIraboh8NwyywHwg/view? usp=sharing ) pada angkutan transportasi umum dilakukan melalui peningkatan, pengawasan dibidang lalu lintas dan angkutan jalan yang lebih intensif. Upaya penegakan hukum dilaksanakan lebih efektif melalui perunusan ketentuan hukum yang lebih jelas serta penerapan sanksi yang lebih tegas untuk menekan angka pelanggaran lalu lintas dan kecelakaan. Hal yang paling berpengaruh dalam permasalahan upaya penegakan hukum adalah komitmen aparat dalam menggunakan hukum, hal ini dikarenakan aparat merupakan bagian dari dari system hukum yang sangat menentukan dalam upaya pencapaian tujuan hukum. Berikut tampilan depan dari UU lalulintas No 22 tahun 2009 yang telah disebar ke supir AKDP secara online pada Gambar 5

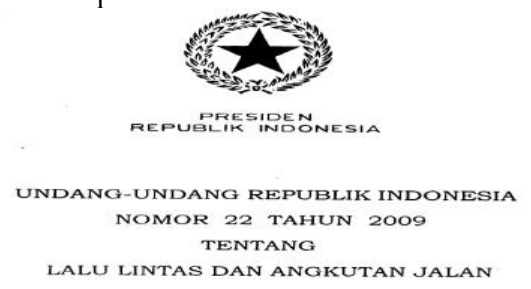

Gambar 5. UU lalulintas No 22 tahun 2009

\subsection{Masyarakat Sasaran}

Yang menjadi sasran dalam kegiatan pengabdian ini adalah para supir AKDP yang berada di Terminal Mallengkeri Kota Makassar, Provinsi Sulawesi Selatan. 


\section{Tinjauan Hasil yang dicapai}

Berikut hasil yang didapatkan dari pretest dilapangan diperlihatkan pada Gambar 5. Apakah Anda mengetahui tentang rambu-rambu lalulintas? 31 jawaban

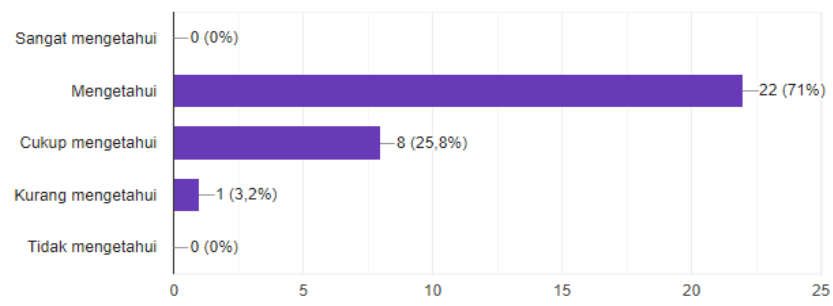

Apakah Anda mengetahui tentang PP RI No 55 tahun 2012 tentang kendaraan? 31 jawaban

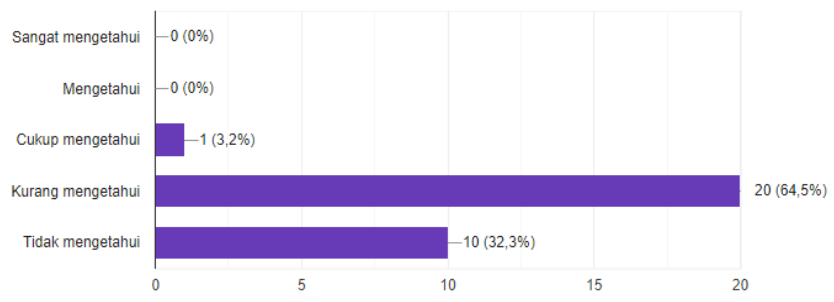

Apakah Anda mengetahui tentang UU No 22 tahun 2009 tentang lalulintas dan angkutan jalan? 31 jawaban

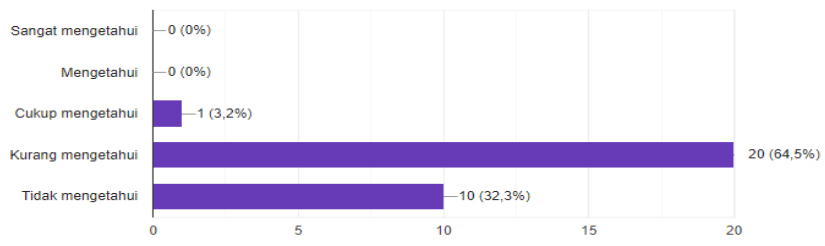

Apakah Anda mengetahui tentang hukum yang berlaku bagi pelanggar lalulintas? 31 jawaban

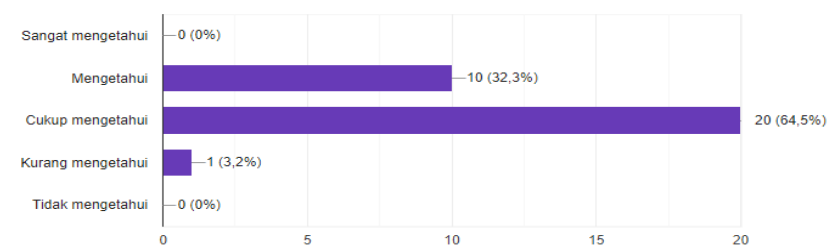

Apakah Anda mengetahui tentang arti dari Keselamatan Transportasi? 31 jawaban

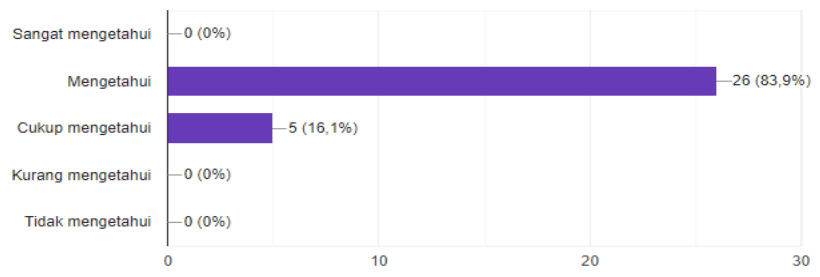

Gambar 6. Hasil Pretest

Berdasarkan hasil pretest yang dilakukan dilapangan sebelum sosialisasi, terlihat bahwa para supir masih banyak yang belum memahami secara tepat tentang persyaratan laik jalan. Namun hampir semua supir AKDP yang berada dilokasi sosialisasi telah mengetahui tentang rambu lalu lintas. Setelah sosialisator melakukan sosialisasi, maka tahapan tes selanjutnya adalah post-test guna mengetahui sejauh mana tingkat pemahaman supir AKDP tentang tujuan sosialisasi. Dari hasil 
penilaian, diketahui bahwa para supir telah mengetahui tentang persyaratan laik kendaraan serta hukum pelanggaran yang berlaku dalam berlalulintas. Hal ini disajikan dalam Gambar 7

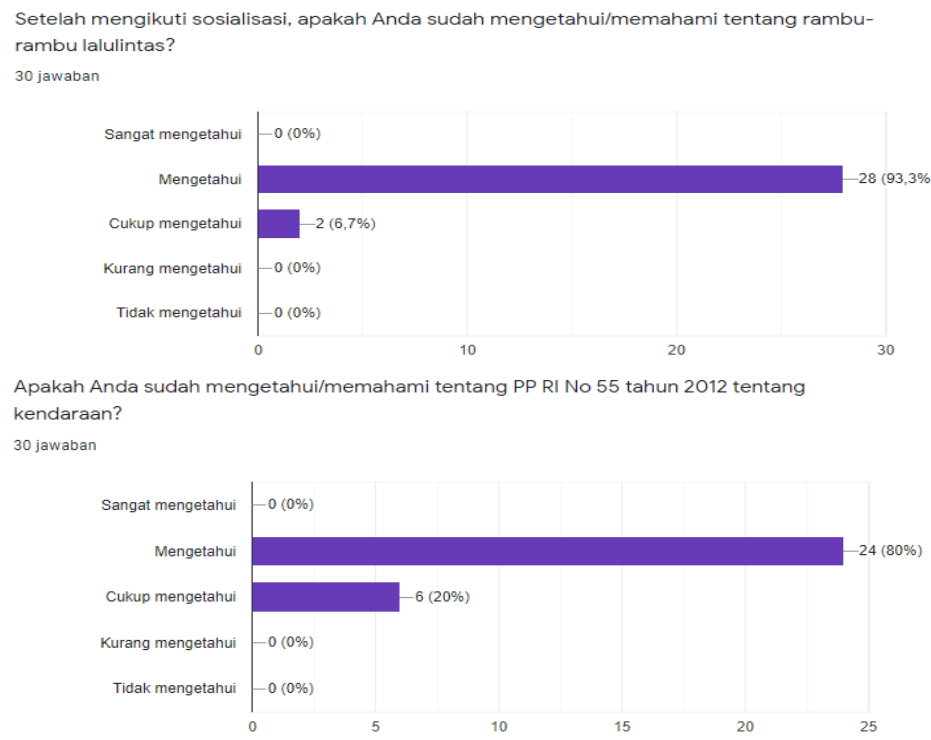

Apakah Anda sudah mengetahui/memahami tentang UU No 22 tahun 2009 tentang lalulintas dan angkutan jalan? 30 jawaban

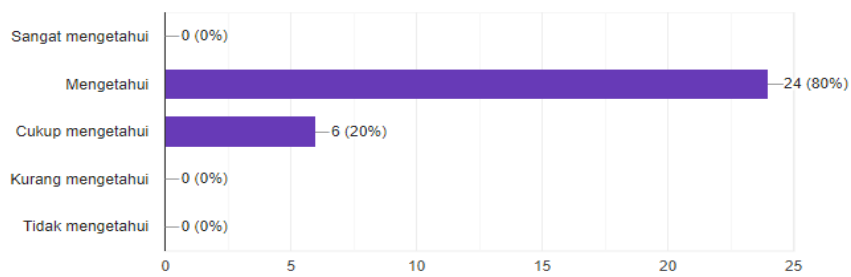

Apakah Anda sudah mengetahui/memahami tentang hukum yang berlaku bagi pelanggar lalulintas?

30 jawaban

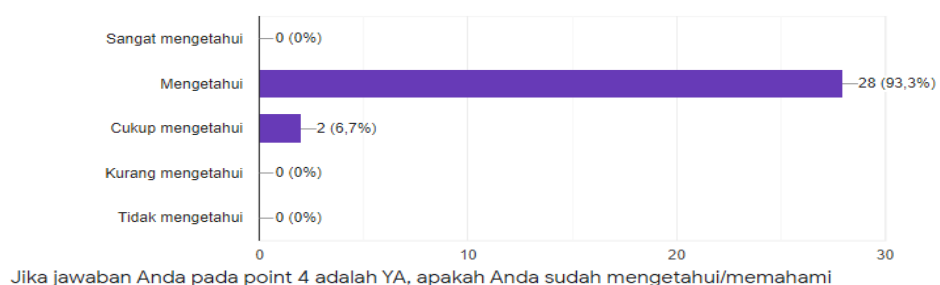

Jika jawaban Anda pada point 4 adalah YA, apakah Anda sudah mengetahui/memahami tentang arti dari Keselamatan Transportasi?

30 jawaban

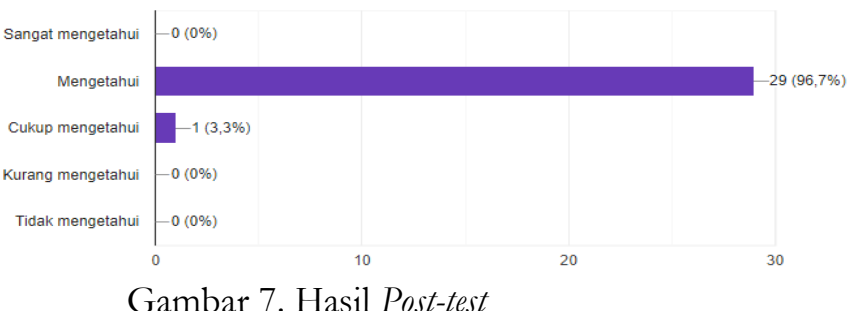




\section{Kesimpulan}

Berdasarkan hasil pembahasan diatas, maka dapat ditarik simpulan bahwa kegiatan sosialisasi ini berjalan sesuai yang diharapkan yaitu meningkatkan pemahaman para supir AKDP tentang pentingnya keselamatan transportasi. Kegiatan ini dilakukan menjelang akhir tahun, menuju libur Natal dan tahun baru. Berdasarkan hasil post-test yang telah dilakukan sesaat setelah sosialisasi, terlihat bahwa supir AKDP sudah mengetahui tentang PP RI No 55 tahun 2012 tentang kendaraan dan UU No 22 tahun 2009 tentang lalu lintas dan angkutan jalan. Dari kegiatan ini diharapkan kesadaran akan keselamatan transportasi dapat diterapkan oleh supir khususnya AKDP dalam setiap perjalanan dan diharapkan undang-undang mengenai tanggung jawab angkutan umum terhadap penumpang senantiasa disosialisasikan.

\section{Daftar Pustaka}

[1] Miro, F., 2012. Pengantar Sistem Transportasi. Jakarta: Erlangga.

[2] Permenhub. 2015. PM 26 Standar Keselamatan Lalu Lintas Dan Angkutan Jalan.

[3] Warpani, S.P., 2002. Pengelolaan lalu lintas dan angkutan jalan. Penerbit ITB.

[4] Wulansari, I., 2021. Penyuluhan Keselamatan Transportasi Darat Usia Transisi (Remaja ke Dewasa). Alfatina: Journal of Community Services, 1(1), pp.17-21.

[5] Akbar, S.A., 2017. Tinjauan Hukum Terbadap Pelanggaran Lalu Lintas Yang Dilakukan Alat Transportasi Umum (Tinjauan Terhadap Undang-Undang Lalu Lintas No. 22 Tahun 2009) Di Kota Makassar (Doctoral dissertation, Universitas Islam Negeri Alauddin Makassar).

[6] Mead, G.H. and Schubert, C., 1934. Mind, self and society (Vol. 111). Chicago: University of Chicago press.

[7] Permenhub. 2014. No. PM 13 Rambu Lalu Lintas.

[8] Kementrian PU Bina Marga. 2012. Panduan Teknis Rekayasa Keselamatan Jalan Direktur Jenderal Bina Marga. Instruksi Direktur Jenderal Bina Marga Nomor : 02/In/Db/2012. Jakarta.

[9] PP No 55. 2012. Persyaratan Teknis dan Laik Jalan Kendaraan Bermotor. Bagian 1. Pasal 1pasal 63

[10] Undang - Undang No. 22. 2009. Undang-undang (UU) tentang Lalu Lintas Dan Angkutan Jalan. LN. 2009/ No. 96, TLN NO. 5025 